\title{
Influence of storage temperature and different packaging on the physicochemical quality of fresh-cut 'Perola' pineapple
}

\author{
Influencia de la temperatura de almacenamiento y diferentes empaques \\ en la calidad físicoquímica de la piña 'Perola' recién cortada
}

Paula Cristina Carvalho Lima ${ }^{*}$, Bianca Sarzi de Souza ${ }^{2}$, Selina Fyfe ${ }^{3}$

\begin{abstract}
This study evaluated the effects of storage temperature and different packaging on the physicochemical aspects of fresh-cut pineapple cv. 'Perola'. Fruits were selected, washed and sanitized, and then stored for $12 \mathrm{~h}$ at $10^{\circ} \mathrm{C}$. At $12^{\circ} \mathrm{C}$, the fruits were peeled and cut into 1.5-2-cm thick semicircle-shaped slices. Cut pieces were rinsed, drained and packed either into polyethylene terephthalate (PET) packaging or on Styrofoam trays wrapped in polyvinyl chloride (PVC) film and stored at 4 or $8{ }^{\circ} \mathrm{C}$ at $90 \%$ of relative humidity. During storage, they were evaluated for color values (lightness, hue angle and chroma), texture, appearance, weight loss, titratable acidity (TA), soluble solids content (SS), SS/TA ratio, $\mathrm{pH}$, vitamin $\mathrm{C}$ and soluble sugars. According to the physicochemical results, the fresh-cut pineapple cv. 'Perola' maintained better quality for consumption and sale at $4{ }^{\circ} \mathrm{C}$, with a fresh product quality up to nine days. Storage on a Styrofoam tray wrapped in PVC film led to greater weight loss, but better appearance, additionally showed good maintenance of the physicochemical parameters of the fruit during the storage period.
\end{abstract}

Key words: Ananas comosus. Fresh-cut. Quality. Postharvest. Storage.

\section{RESUMEN}

En este estudio se evaluaron los efectos de la temperatura de almacenamiento y diferentes empaques en los aspectos fisicoquímicos de piña cv. Pérola recién cortada. Los frutos fueron seleccionados, lavados, desinfectados y luego almacenados durante 12 h a $10^{\circ} \mathrm{C}$. Después de esto, a $12{ }^{\circ} \mathrm{C}$, las frutas fueron peladas y cortadas en rodajas semicirculares de 1,5-2 cm de grosor. Las piezas cortadas se enjuagaron, drenaron y embalaron en embalajes de tereftalato de polietileno (TPE) o en bandejas de espuma de poliestireno envueltas en película de cloruro de polivinilo (CPV) y almacenadas a 4 u $8{ }^{\circ} \mathrm{C}$ a $90 \%$ de humedad relativa. Durante el almacenamiento fueron evaluadas para los valores de color (luminosidad, ángulo hue y croma), textura, apariencia, pérdida de peso, acidez titulable (AT), contenido de sólidos solubles (SS), relación SS/AT, pH, vitamina C y azúcares solubles. Según los resultados fisicoquímicos, la piña cv. Pérola recién cortada ha mantenido una mejor calidad para el consumo y la comercialización a $4{ }^{\circ} \mathrm{C}$, con calidad de producto fresco de hasta nueve días. El almacenamiento en bandejas de espuma de poliestireno envueltas en película de CPV condujo a una mayor pérdida de peso, pero una mejor apariencia. Adicionalmente la fruta mostró buen mantenimiento de los parámetros fisicoquímicos durante el período de almacenamiento.

Palabras clave: Ananas comosus, recién cortado, calidad, poscosecha, almacenamiento.

\section{Introduction}

The pineapple (Ananas comosus) is a commonly consumed fruit with excellent organoleptic qualities. It is also a good source of vitamins, sugars and fiber that helps in the digestive process (Figueirêdo et al., 2003). Brazil produced around 1.7 million tons of pineapple in 2015. The main producing zones are the southeast and northeast regions, with Minas Gerais State accounting for $15 \%$ of the national production (I.B.G.E., 2016).

Modern consumers have less time to prepare their food and therefore prefer healthy foods that are easily quickly prepared (Buckley et al., 2007).

\footnotetext{
1 Plant Biology Department, Federal University of Viçosa, Avenida Peter Henry Rolfs, s/n, Viçosa, Minas Gerais, Brazil.

2 IFSULDEMINAS - Muzambinho Campus, Estrada Muzambinho, km 35 - Bairro Morro Preto Muzambinho, Minas Gerais, Brazil.

3 School of Agriculture and Food Sciences, The University of Queensland, St Lucia QLD 4072 Australia.

* Corresponding author: paula.c.lima@ufv.br.
} 
In this context, minimal processing methods can be used, as they are techniques that preserve food while maintaining most of its nutritional qualities and sensory characteristics (Olsen et al., 2012). The quality of minimally processed products is determined from the combination of attributes that contribute to their nutritional value and, more importantly, their appearance. The product must have a fresh appearance, have a consistent, acceptable color and be reasonably free of pesticides and contamination (Gonzalez et al., 2006).

Mechanical injuries that occur to tissues during peeling and cutting operations lead to metabolism acceleration, increases in respiratory rate and ethylene production and a consequent decrease in the shelf life of the food. The injured product matures rapidly, making it more susceptible to microorganism attack (Oliveira et al., 2006). Physiological and biochemical changes begin at the acquisition of raw materials, through the processing modifications, and end with packaging factors that affect the quality and shelf life of the product (González-Aguilar et al., 2010).

The use of suitable packaging and storage temperature is essential for maintaining the quality of food and contributes to a longer shelf life. Packaging minimizes the water loss, acts as a protective barrier and reduces the respiration rate during storage, in addition to facilitating the transport, handling and sale of the item (Carnelossi et al., 2002).

Research has been developed on minimally processed pineapple because of its economic importance and in an attempt to increase its consumption. The present study was conducted to evaluate physicochemical aspects related to the influence of storage temperature and package type on the minimally processed pineapple cv. 'Perola'.

\section{Material and methods}

The 'Perola' pineapples were purchased at a local market in Muzambinho-MG, Brazil, at the commercial maturation stage (each berry on the fruit had a yellow center), without detectable physiological defects or infections. The fruit were transported to the industry sector of the Federal Institute of the South of Minas Gerais - Muzambinho Campus, where they went through a process of selection, washing, sanitization with sodium hypochlorite (200 mg.L ${ }^{-1}$ ) and storage for $12 \mathrm{~h}$ at $10^{\circ} \mathrm{C}$. After cold storage, the fruit were moved to a cold room $\left(12{ }^{\circ} \mathrm{C}\right)$ where they were peeled and cut into 1.5-2-cm-thick slices that were then cut in half to give semicircular-shaped pieces. They were then rinsed in sodium hypochlorite (20 mg.L $\mathrm{L}^{-1}$ ), drained and packed either in polyethylene terephthalate (PET) containers or on Styrofoam trays wrapped in polyvinyl chloride (PVC) film and stored at 4 or $8^{\circ} \mathrm{C} \mathrm{C}$ at $90 \%$ of relative humidity. Sources of contamination during processing were minimized by sanitizing utensils with a sodium hypochlorite solution (200 mL.L $\mathrm{L}^{-1}$ ); operators wore gloves, aprons, caps and masks.

The following physical characteristics of the fruit were evaluated during storage: color - determined using a chroma meter that expressed the results according to the system proposed by Commission Internationale de L'eclaraige (CIE) in the $\mathrm{L}^{*} \mathrm{a}^{*} \mathrm{~b}^{*}$ color space, reported as the variables lightness $\left(\mathrm{L}^{*}\right)$, color (hue angle) and chromaticity (chroma); texture - obtained using a penetrometer with an 8-mm tip, with three pieces of fruit in each package tested and results expressed in Newtons; appearance - recorded and evaluated using a 5 -point scale where $1=$ great ("fresh" appearance and natural color), $2=$ good, 3 $=$ regular (signs of wilting and/or drying and early softening), $4=$ poor and $5=$ very poor (wilting and/ or dryness, darkening and softening), in which the minimally processed product was considered still suitable for sale if scoring up to 3 on the scale; and weight loss - measured using an analytical scale with 1200-g capacity and 0.1-g accuracy, calculated as the difference between the final weight and the initial weight of the package.

The following chemical characteristics of the fruit were evaluated during storage: titratable acidity (TA) - measured on $10 \mathrm{~g}$ samples of homogenized pulp which were titrated with a standard $0.1 \mathrm{~N}$ sodium hydroxide solution until the samples reached $\mathrm{pH}$ 8.1, with results expressed as g citric acid.100 $\mathrm{g}^{-1}$ (A.O.A.C., 2012); soluble solids content (SS) obtained using a digital refractometer with results expressed in ${ }^{\circ}$ Brix (A.O.A.C., 2012); soluble solids/ titratable acidity (SS/TA) - determined as the ratio between the involved variables; $\mathrm{pH}$ - determined using a potentiometer (A.O.A.C., 2012); vitamin $\mathrm{C}$ content - quantified in pulp homogenate that was diluted with sufficient amounts of $5 \%$ oxalic acid and then titrated with Tillman reagent $(0.1 \%$ sodium 2.6-dichlorophenolindophenol), with results expressed as $\mathrm{mg}$ ascorbic acid.100 $\mathrm{g}^{-1}$ of pulp (A.O.A.C., 2012); and soluble sugars content determined using the spectrophotometer methodology 
described by Dubois et al. (1956), with a $0.2 \%$ sucrose solution used as the standard for construction of the analytical curve (concentrations of 0 to $50 \mu \mathrm{g} \mathrm{L}^{-1}$ ), by the phenol-sulfuric method, with absorbance read at $490 \mathrm{~nm}$ and results expressed as g sucrose $100 \mathrm{~g}^{-1}$.

During storage, three replicates of $25 \mathrm{~g}$ of sample were transferred to $225 \mathrm{~mL} 0.1 \%$ peptone water, and from this, dilutions up to $10^{-4}$ were prepared. Afterwards, microbiological analyses were performed using the method described by Silva et al. (2010). The presence of Staphylococcus was evaluated by surface-scattering in Baird-Parker agar medium and incubated at $35^{\circ} \mathrm{C}$ for $48 \mathrm{~h}$. The presence of Salmonella sp. was determined with pre-enrichment in lactose broth, with incubation at $35^{\circ} \mathrm{C}$ for $24 \mathrm{~h}$, followed by selective enrichment in tetrathionate broth and Rappaport's broth at 35 and $42{ }^{\circ} \mathrm{C}$, respectively, for $24 \mathrm{~h}$. For total and fecal coliforms, the most probable number (MPN.g-1) technique was adopted, in which aliquots were inoculated in Lauryl Sulphate Tryptose broth (LST) with an inverted Duhran tube (presumptive test). Tubes were incubated at $35^{\circ} \mathrm{C}$ for $24-48 \mathrm{~h}$. Confirmatory tests for thermotolerant coliforms in Escherichia coli broth (EC) at $45.5^{\circ} \mathrm{C}$ for $24 \mathrm{~h}$ were performed in the tubes with positive reading (turbidity and gas formation).

Four replicates were used for the physical and chemical characteristics, where each experimental unit was represented by a package containing 300-400 g of product. A completely randomized experimental design was adopted with a $4 \times 4$ factorial arrangement where factors were represented by the packing type/temperature and time of storage. Data was subjected to an analysis of variance, and the means of the analyzed parameters were subjected to the Tukey test at the 5\% error-probability level. To check the interactions between the factors, the results of the analysis of variance were analyzed using a polynomial regression considering equations up to the 3rd degree. The minimum determination coefficient for the use of the curves was 0.80 . Statistical analysis was performed using the Sisvar software (Ferreira, 2011). The SigmaPlot 10.0 software was used for graph design.

\section{Results and discussion}

During storage, the PET packing at $4{ }^{\circ} \mathrm{C}$ temperature maintained stable lightness of the pineapple pieces. There was greater variability in lightness in samples stored in PET packing at $8{ }^{\circ} \mathrm{C}$ and on Styrofoam trays wrapped in PVC film stored at $4{ }^{\circ} \mathrm{C}$ (Figure 1A). Overall, there was a decrease in the $\mathrm{L}^{*}$ value, probably due to the decompartmentalization of the enzymes and substrates, which led to browning reactions. At five days of storage, there were variations in the hue angle of the products, with higher storage temperatures causing more fluctuation in color than the package type (Figure 1B). Samples stored at $4{ }^{\circ} \mathrm{C}$ showed lower means, indicating a more intense yellow coloration, while those in storage at $8^{\circ} \mathrm{C}$ had the highest mean values, indicating a light-yellow coloration. In those stored at $8{ }^{\circ} \mathrm{C}$, there was greater discoloration in the pulp, while those at $4{ }^{\circ} \mathrm{C}$ maintained the yellow color of the product better, similar to that of fresh fruit. Chroma values did not show large variations between samples and over storage time (Figure 1C).

There was variability in texture changes in the products (Figure 1D), and temperature had a greater influence than the storage container on this variable, which increased at $4{ }^{\circ} \mathrm{C}$ and decreased at $8{ }^{\circ} \mathrm{C}$. An increase in texture may be caused by moisture loss, which promotes the formation of resistant surface tissue and causes the pieces to become firmer (Souza et al., 2005). However, softening of minimally processed fruits occurs because of metabolic disorders in the plant tissues, which is mostly due to the degradation of polysaccharides such as starch and cell wall substances, culminating in changes in sensory attributes such as texture, flavor and aroma and even changes in nutritional quality, significantly reducing the shelf life of these products (Melo \& Vilas Boas, 2007).

The minimally processed products stored in Styrofoam packing at $4^{\circ} \mathrm{C}$ maintained adequate appearance for sale, as indicated by a grade below 3 for up to nine days. Products stored in PET packaging at 4 and $8{ }^{\circ} \mathrm{C}$ showed a slight decrease in appearance at nine days of storage (grade 3.25). Lastly, products stored in Styrofoam packing at $8{ }^{\circ} \mathrm{C}$ showed a greater decline in appearance (grade 3.75) at nine days of storage (Figure 1E). Sarzi et al. (2002) also reported that minimally processed pineapple cv. 'Perola' stored at 3 and $6{ }^{\circ} \mathrm{C}$ maintained its appearance and flavor suitable for consumption for up to nine days. 

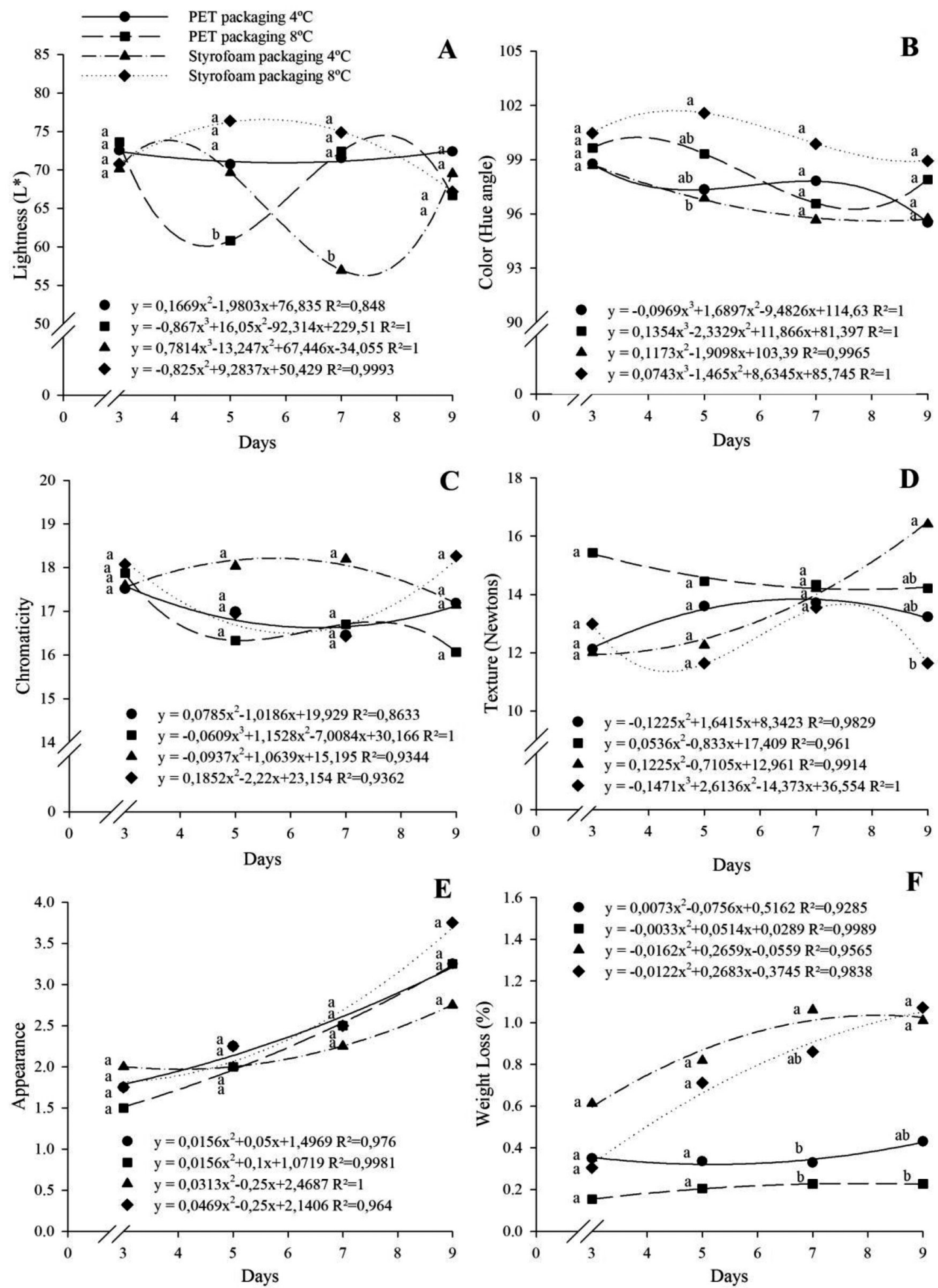

Figure 1. Mean values for lightness ( $\left.\mathrm{L}^{*} ; \mathrm{A}\right)$, color (hue angle; B), chromaticity (chroma; C), texture (D), appearance (E) and weight loss $(\% ; \mathrm{F})$ of minimally processed pineapple cv. 'Perola' stored at 4 and $8{ }^{\circ} \mathrm{C}$. 
Weight loss reduces the quality and shelf life of fruit and vegetables, and storage conditions including high relative humidity and low temperatures can reduce this water loss, minimizing the deterioration of quality attributes (texture, flavor, etc.) (Chitarra $\&$ Chitarra, 2005). During storage time, the weight loss of pineapple was very low due to the protection provided by the packaging (Figure 1F). However, losses in the Styrofoam tray wrapped in PVC film were higher at both temperatures, which were attributed to the higher permeability of the film to water vapor. This behavior was also observed by Sarzi et al. (2002) in minimally processed pineapples, but was not found by Pagliarini et al. (2015), who observed a higher rate of weight loss in Smooth Cayenne pineapples packed in PET packages under refrigeration.

Titratable acidity (TA) was fairly constant in the products packed on Styrofoam trays wrapped with PVC film, while in products packed in PET at $8{ }^{\circ} \mathrm{C}$ it increased and then decreased, and those packed in PET at $4{ }^{\circ} \mathrm{C}$ had an overall increase through the nine days of storage (Figure 2A). Figueirêdo et al. (2003) studied minimally processed pineapple and observed reductions in TA levels at $5{ }^{\circ} \mathrm{C}$ and increases in those stored at $9{ }^{\circ} \mathrm{C}$. Santos et al. (2005) also observed an increase in TA in minimally processed pineapple cv. 'Perola' at $5^{\circ} \mathrm{C}$ whereas Moda et al. (2008) observed an increase in minimally processed 'Smooth Cayenne' pineapple at $5{ }^{\circ} \mathrm{C}$.

Organic acids typically decrease during storage, because they are used during respiration or converted to sugars, as occurs in minimally processed pequi (Caryocar brasiliense) stored at $6^{\circ} \mathrm{C}$ for 15 days. However, in some fruits, they may increase, as occurs in banana and pineapple, reaching high levels in the full maturation stage (Damiani et al., 2008). The variations found can be attributed to changes in concentrations of organic acids, which can be dissolved in the cell vacuoles or found in free form or in combination; e.g. salts, esters, glycosides, etc. (Chitarra \& Chitarra, 2005).

The pineapple in this study showed only slight changes in soluble solids (SS) contents during storage (Figure 2B), this is because the pineapple is a non-climacteric fruit that stops accumulating soluble solids and has a reduced metabolism (Chitarra \& Chitarra, 2005). However, higher SS values were detected in the products stored at $4{ }^{\circ} \mathrm{C}$ then at $8^{\circ} \mathrm{C}$. Results are similar to those found by Figueirêdo et al. (2003), who obtained reductions in soluble solids contents at higher temperatures due to consumption of the substrates in metabolism. The SS/TA ratio showed a response to that of soluble solids, and was also influenced by storage temperature (Figure 2C), as the products stored at $4{ }^{\circ} \mathrm{C}$ had higher values, indicating they would have a sweeter taste.

During storage, the $\mathrm{pH}$ values remained stable at $4{ }^{\circ} \mathrm{C}$ but had slightly lower values and some changes during the $8{ }^{\circ} \mathrm{C}$ storage (Figure 2D). Figueirêdo et al. (2003) reported that, regardless of the package used, the $\mathrm{pH}$ was higher at $5^{\circ} \mathrm{C}$ and lower at $9{ }^{\circ} \mathrm{C}$ in minimally processed pineapples stored for 10 days.

Vitamin $\mathrm{C}$ content was influenced by storage temperature, with higher values at $4{ }^{\circ} \mathrm{C}$ (Figure 2E). There were only minor changes in it during storage, with results higher than those found by Figueirêdo et al. (2003) for minimally processed pineapple stored at 5 and $9{ }^{\circ} \mathrm{C}$. However, the present values for vitamin $\mathrm{C}$ exhibited a similar response during storage, with higher values in those stored at $5{ }^{\circ} \mathrm{C}$ until the 6th day of storage.

Soluble sugars showed variations during storage, with greater increases in the products stored in PET packaging at $4{ }^{\circ} \mathrm{C}$ and products in Styrofoam trays wrapped in PVC film and stored at $8{ }^{\circ} \mathrm{C}$ (Figure $2 \mathrm{~F}$ ). The variations observed in the soluble sugars contents may be related to the process of senescence or fruit ripening, which causes a number of changes including hydrolysis of polysaccharides reserves, sugar interconversion, synthesis and/or degradation of organic acids and water loss from the fruit. These changes appear to be synchronized and are probably under genetic control (Chitarra \& Chitarra, 2005).

The control of the hygienic conditions during the handling of the products appeared to be sufficient, as the presence of Salmonella sp. and Staphylococcus was not detected during storage. The presence of thermotolerant coliforms $\left(45^{\circ} \mathrm{C}\right)$ did not reach $<0.3$ MPN. $g^{-1}$ during storage, which is lower than the $10^{2} \mathrm{MPN}_{\mathrm{g}} \mathrm{g}^{-1}$ allowed by the Brazilian legislation (RDC no. 12 of 01/02/2001) (Brasil, 2001).

\section{Conclusions}

The results of the physicochemical and microbiological aspects of fresh-cut pineapple cv. 'Perola' during storage showed it maintained 

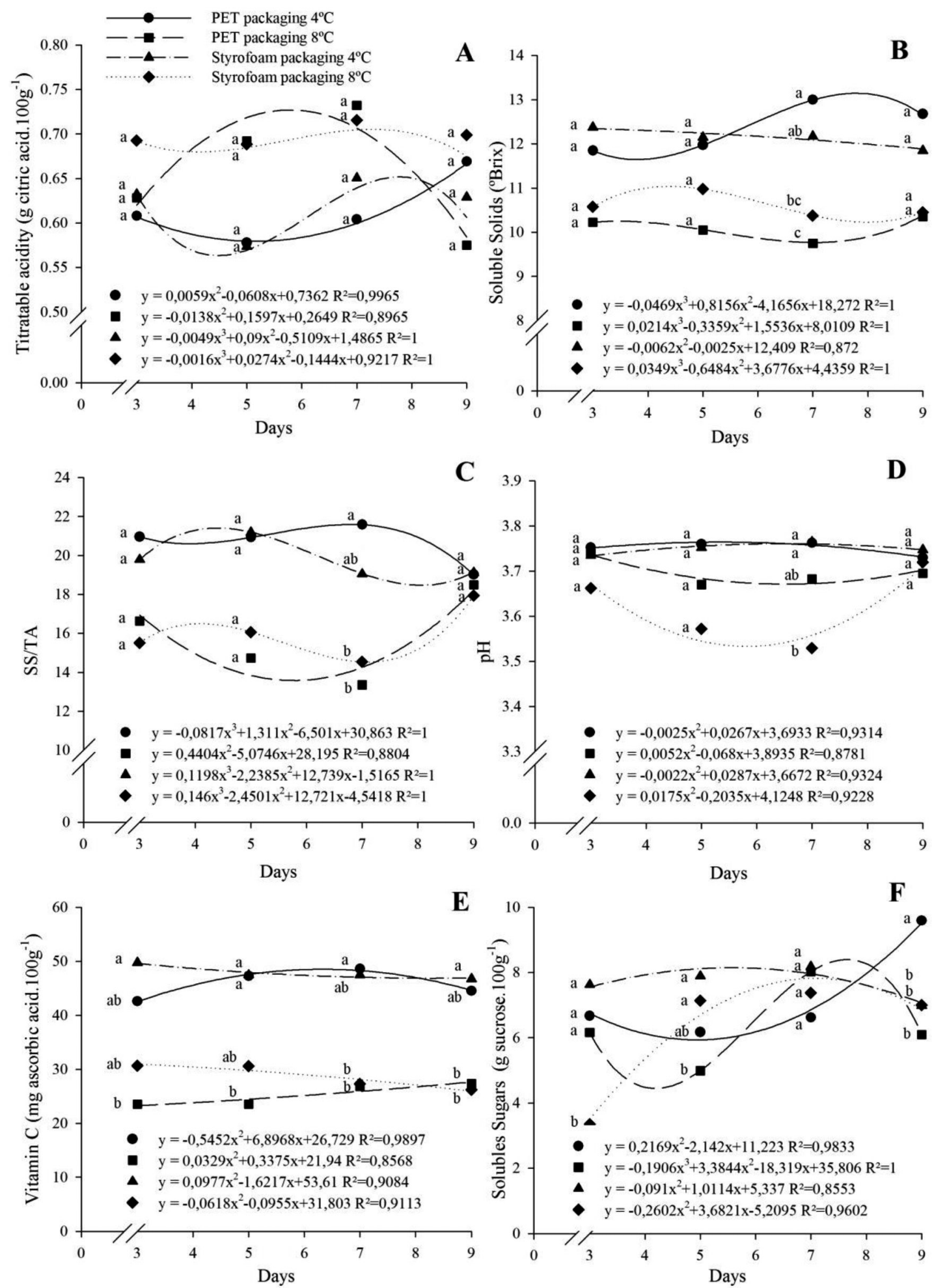

Figure 2. Mean values for titratable acidity (g citric acid. $100 \mathrm{~g}^{-1}$; A), soluble solids $\left({ }^{\circ}\right.$ Brix; B), SS/TA ratio (C), $\mathrm{pH}(\mathrm{D})$, vitamin $\mathrm{C}\left(\mathrm{mg}\right.$ ascorbic acid.100 $\left.\mathrm{g}^{-1} ; \mathrm{E}\right)$ and soluble sugars ( $\mathrm{g}$ sucrose $\left.100 \mathrm{~g}^{-1} ; \mathrm{F}\right)$ of minimally processed pineapple cv. 'Perola' stored at 4 and $8{ }^{\circ} \mathrm{C}$. 
a better quality for consumption and sale when stored in Styrofoam packaging at $4{ }^{\circ} \mathrm{C}$, with a fresh product quality up to nine days. Compared with PET containers, packaging pineapple on a Styrofoam tray wrapped in PVC film led to higher weight loss in the fruit but better appearance during the storage period as well as maintenance of better physicochemical parameters.

\section{Acknowledgments}

The authors thank FAPEMIG (Research Support Foundation of the State of Minas Gerais) for the project financing (APQ-00926-09) and the scholarship grant awarded and Federal Institute of Education, Science and Tecnology of South of Minas Gerais - IFSULDEMINAS.

\section{Literature Cited}

AOAC. Association of Official Analytical Chemistry.

2012. Official methods of analysis. AOAC International (Eds.) $19^{\text {nd }}$ Edition. Gaithersburg, USA. 3000 p.

Buckley, M.; Cowan, C.; McCarthy, M.

2007. The convenience food market in Great Britain: Convenience food lifestyle (CFL) segments. Appetite, 49(3): 600-617.

Brasil. Ministério da Saúde. Agência Nacional de Vigilância Sanitária.

2001. Resolução no 12 da diretoria colegiada (RDC), de 2 de janeiro de 2001 - Definição de critérios e padrões microbiológicos para alimentos. Available: http://portal.anvisa.gov. br/documents/33880/2568070/RDC_12_2001.pdf/15ffddf63767-4527-bfac-740a0400829b. Consulted: 24/ oct/ 2017.

Carnelossi, M.A.G.; Silva, E.O.; Campos, R.S.; Soares N.F.F.;

Minim V.P.R.; Pushmann, R.

2002. Conservação de folhas de couve minimamente processadas. Revista Brasileira de Produtos Agroindustriais, 4(2): 149-155.

Chitarra, M.I.F.; Chitarra, A.B.

2005. Pós-colheita de frutas e hortaliças: fisiologia e manuseio. FAEPE - Fundação de Apoio ao Ensino, Pesquisa e Extensão (Eds.) $2^{\mathrm{a}}$ Edição. Lavras, Brasil. 785 p.

Damiani, C.; Vilas-Boas, E.V.B.; Pinto, D.M.; Rodrigues, L.J. 2008. Influência de diferentes temperaturas na manutenção da qualidade de pequi minimamente processado. Ciência e Agrotecnologia, 32(1): 203-212.

Dubois, M.; Gilles, K.A.; Hamilton, J.K.; Reber P.A.; Smith F. 1956. Colorimetric method for determination of sugar and related substances. Analytical Chemistry, 2(3): 350-356.

Ferreira, D.F.

2011. Sisvar: a computer statistical analysis system. Ciência e Agrotecnologia, 35(6): 1.039-1.042.

Figueirêdo, R.M.F.; Queiroz, A.J.M.; Noronha, M.A.S. 2003. Armazenamento de abacaxi minimamente processado. Revista Brasileira de Produtos Agroindustriais, Volumen especial(1): 95-103.

Gonzalez, A.F.; Ayub, R.A.; Reghin, M.Y.

2006. Conservação de rúcula minimamente processada produzida em campo aberto e cultivo protegido com agrotêxtil. Revista de Horticultura Brasileira, 24(3): 360-362.

González-Aguilar, G.A.; Ayala-Zavala, J.F.; De La Rosa, L.A.; Ivarez-Parrilla E.A.

2010. Preserving quality of fresh-cut product using safe technology. Journal für Verbraucherschutz und Lebensmittelsicherheit, 5(1): 65-72.
IBGE. Instituto Brasileiro de Geografia e Estatística.

2016. Levantamento sistemático da produção agrícola: pesquisa mensal de previsão e acompanhamento das safras agrícolas no ano civil. Instituto Brasileiro de Geografia e Estatística, 29(12): 1-79.

Melo, A.A.M.; Vilas Boas, E.V.B.

2007. Redução do amaciamento de banana maçã minimamente processada pelo uso de tratamentos químicos. Ciência e Agrotecnologia, 26(1): 821-828.

Moda, E.M.; Pilon, L.; Zocchi, S.S.; Spoto, M.H.F.

2008. Qualidade físico-química e sensorial de abacaxi minimamente processado e irradiado. Boletim CEPPA, 26(2): 267-276.

Oliveira, A.M.C.; Costa, J.M.C.; Maia, G.A.

2006. Qualidade higiênico-sanitária de abacaxi "Perola" minimamente processado. Revista Brasileira de Promoção de Saúde, 19(1): 19-24.

Olsen, N.V.; Menichelli, E.; Sørheim, O.; NAES, T.

2012. Likelihood of buying healthy convenience food: an at-home testing procedure for ready-to-heat meals. Food Quality and Preference, 24(1): 171-178.

Pagliarini, M.K.; Mariano-Nasser, F.A.C.; Mendonça, V.Z. et al. 2015. Influência de embalagens no processamento mínimo de abacaxi Smooth Cayenne. Revista Tecnologia e Ciência Agropecuária, 9(4): 63-70.

Santos, J.B.C.; Vilas-Boas, E.V.B.; Prado, M.E.T.; Pinheiro A.C.M. 2005. Avaliação da qualidade do abacaxi 'Perola' minimamente processado armazenado sob atmosfera modificada. Ciência e Agrotecnologia, 29(2), 353-361.

Sarzi, B.; Durigan, J.F.; Rossi Junior, O.D.

2002. Temperatura e tipo de preparo na conservação de produto minimamente processado de abacaxi 'Pérola'. Revista Brasileira de Fruticultura, 24(2): 376-380.

Silva, N.; Junqueira, V.C.A.; Silveira, N.F.A.; Taniwaki M.H.; Santos R.F.S.; Gomes R.A.R.

2010. Manual de métodos de análise microbiológica de alimentos e Água. Varela (Eds.) $4^{\mathrm{a}}$ Edição. São Paulo, Brasil. 624 p.

Souza, B.S.; Durigan, J.F.; Donadon, J.R.; Teixeira, G.H.A. 2005. Conservação de mamão "Formosa" minimamente processado armazenado sob refrigeração. Revista Brasileira de Fruticultura, 27(2): 273-276. 
